\title{
STUDIES OF PROTOPORPHYRIN: IV. A COMPARISON OF THE ERYTHROCYTE PROTOPORPHYRIN CONCENTRATION WITH THE RETICULOCYTE PERCENTAGE UNDER EXPERI- MENTAL AND CLINICAL CONDITIONS ${ }^{1}$
}

\author{
By C. J. WATSON, MOISÉS GRINSTEIN,2 AND VIOLET HAWKINSON \\ (From the Division of Internal Medicine, University of Minnesota Hospital, Minneapolis)
}

(Received for publication July 12, 1943)

The presence of protoporphyrin in human erythrocytes was first noted by $\mathrm{H}$. van den Bergh and co-workers $(1,2)$. Grotepass (3) isolated this porphyrin and identified it as protoporphyrin 9, corresponding to aetioporphyrin III; in other words, the same protoporphyrin as that in the hemoglobin molecule. The significance of the erythrocyte protoporphyrin is not yet clear. Watson and Clarke (4) described evidence indicating that much of it is contained in the reticulocytes. This was likewise the conclusion of de Langen and Grotepass (5). In Watson and Clarke's study (4), it was shown that upon centrifuging various samples of blood, the protoporphyrin was regularly found in the upper, or reticulocyte-rich, strata. It was also observed that samples of red cells composed entirely of reticulocytes, as obtained from rabbits with acute phenylhydrazine poisoning, were especially rich in protoporphyrin. At that time, a satisfactory method for quantitative determination of the erythrocyte protoporphyrin was not available and consequently, the question of correlation of the amount of porphyrin with the reticulocyte percentage, in various clinical and experimental conditions, could not be investigated. In a series of papers appearing between 1933 and 1940, Seggel and others (6 to 10) described evidence indicating that the erythrocyte protoporphyrin resides in "fluorescytes," i.e., red blood cells exhibiting red fluorescence in ultraviolet light. Simultaneous reticulocyte and fluorescyte curves, as obtained in Seggel's studies, were not parallel. Thus, in cases of pernicious anemia which were followed through the reticulocyte response to liver extract therapy, the fluorescytes increased

1 Aided by the Charles P. de Laittre Medical Research Fund, and the Research Fund of the Graduate School, University of Minnesota.

2 Fellow of the Rockefeller Foundation. later and declined more slowly than the reticulocytes. A rough correlation was found to exist between the protoporphyrin content of the red cells and the fluorescyte percentage, in a variety of clinical conditions, as well as in normal individuals. Seggel explained the lack of strict correlation by pointing out that many cells might have too little porphyrin to be visible in the fluorescence microscope, yet, in the aggregate, the amount contained might increase the protoporphyrin value significantly ; conversely, the percentage of fluorescytes might be well above Seggel's observed normal of 0.1 per cent; yet if all of the non-fluorescytes contained no protoporphyrin, the value for the latter might be relatively low. Obviously, some difficulty was experienced in counting the fluorescytes. This may be judged by a statement in Seggel's last paper that cells with but moderate fluorescence were visible for not more than 15 seconds at most. The rapid disappearance of fluorescence was ascribed to a damaging effect of the ultra-violet light. This is quite in accord with the observation of a similar deterioration of protoporphyrin when exposed to ultraviolet light, in vitro (13). The method used by Seggel and his associates for determining the erythrocyte protoporphyrin can hardly have permitted anything more than a rough approximation. Seggel concluded that the erythrocyte protoporphyrin is a sign of a partly faulty synthesis of hemoglobin due to iron deficiency, which may be absolute, as in post-hemorrhagic anemia, or relative, as Seggel thought might occur because of (1) unusually rapid regeneration, or (2) interference with utilization of iron in hemoglobin synthesis, as in lead poisoning. The fluorescyte percentages and protoporphyrin values were observed to be very high in the latter condition.

In the first three papers of the present series, improved methods were described for the puri- 
fication of protoporphyrin (11), for its conversion to mesoporphyrin (12), and for the quantitative determination of the erythrocyte protoporphyrin by means of the photoelectric colorimeter (13). The present study was undertaken primarily with the purpose of making simultaneous fluorescyte and reticulocyte counts, and determining the erythrocyte protoporphyrin, in a series of blood samples having different reticulocyte percentages and representing various clinical states. In spite of careful attention to the construction of a fluorescence microscope in accordance with Seggel's description (10), we have thus far been unsuccessful in our attempts to visualize fluorescytes satisfactorily. The study has necessarily been limited, therefore, to a comparison of reticulocyte percentage, at various levels and under different conditions, with the amounts of protoporphyrin in the erythrocytes, together with certain additional observations relating to the protoporphyrin alone.

\section{EXPERIMENTAL}

The erythrocyte protoporphyrin was determined by means of the method which we have recently described (13), which utilizes the Evelyn photoelectric colorimeter. For the most part, this method was applied only to the red blood cells. The most satisfactory procedure is as follows: A sample of whole blood is measured and centrifuged. The plasma is discarded. After washing once with physiological saline, the cells are subjected to the procedure previously described. The hematocrit percentage of the whole blood is determined separately in a Wintrobe tube. From this is calculated the volume of red blood cells used for the determination.

The reticulocyte preparations consisted of thin smears of blood superimposed upon and simultaneously mixed with thin films of brilliant cresyl blue on ordinary clean glass slides. The films of the dye were made simply by smearing the slide evenly with a 1 per cent alcoholic solution, and allowing it to dry. Immediately after superimposing the blood smear, the slide is placed in a moist chamber and allowed to stand for 10 minutes to permit supravital staining. After this, it is at once whipped dry. The circular aperture of the microscope ocular to be used is reduced to a square about one-sixth of the original size simply by inserting into the upper chamber of the ocular a round piece of paper with a square cut out of the middle. To further facilitate counting, this square is subdivided into four by two hairs laid at right angles across it, and held in place with glue. With an oil immersion lens, a total of 1,000 erythrocytes is counted and the percentage of reticulocytes noted. Differential reticulocyte counts, according to Heilmeyer's method (14), were also made. This method subdivides the reticulocytes into 4 groups, the relative maturity being indicated by the amount of reticulated substance noted. (For more exact orientation, reference may be made to the illustration in Heilmeyer's paper.)

\section{RESULTS}

1. The first part of the study consisted of observations on 5 rabbits in which acute phenylhydrazine anemia was produced by subcutaneous administration of $50 \mathrm{mgm}$. of phenylhydrazine hydrochloride, dissolved in $1.5 \mathrm{cc}$. of physiological saline. The blood for serial analyses was obtained by cardiac puncture. Potassium oxalate was used as anti-coagulant. The data obtained are shown in Figure 1. The values for the dif-

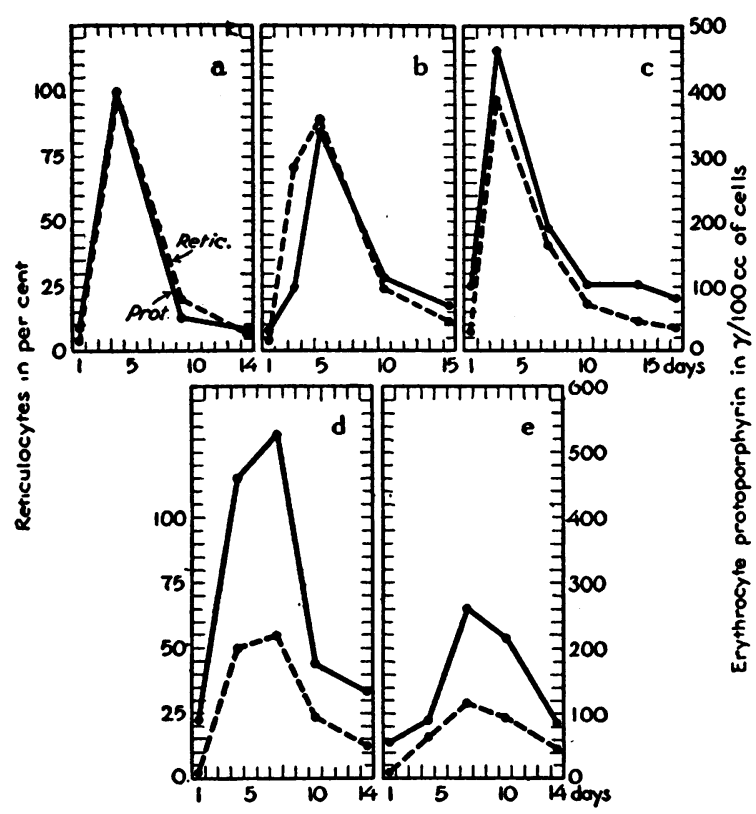

Fig. 1. Erythrocyte Protoporphyrin Concentration and Reticulocyte Percentage in 5 Rabbits (a to e) with Acute Phenylgydrazine Anemia

ferential reticulocyte counts in 4 of the 5 rabbits are given in Table I. The data for the fifth will be omitted in order to conserve space. These data were essentially the same as in the 4 that are given. In experiments $d$ and $e$ in Figure 1, it is seen that the reticulocyte response is smaller in relation to the amount of protoporphyrin than was true in the other 3 animals. The possibility was considered that the reticulocyte response was not as great because of the fact that these 2 rabbits were considerably older than the remaining 3 
TABLE I

Differential reticulocyte counts, according to Heilmeyer, in rabbits with acute phenylhydrazine anemia

The determinations before administration are given in the column under 0 days. All of the values given are percentages.

\begin{tabular}{|c|c|c|c|c|c|c|c|c|c|c|c|c|}
\hline & Rabbit & \multicolumn{6}{|c|}{ A } & \multicolumn{5}{|c|}{ B } \\
\hline & & \multicolumn{6}{|c|}{ Days } & \multicolumn{5}{|c|}{ Days } \\
\hline & & 0 & 3 & 8 & 13 & & & 0 & 2 & 4 & 9 & 14 \\
\hline $\begin{array}{l}\text { Increasing ma- } \\
\text { turity of re- } \\
\text { ticulocytes } \\
\text { from I to IV }\end{array}$ & $\begin{array}{c}\text { I } \\
\text { II } \\
\text { III } \\
\text { IV } \\
\text { Total }\end{array}$ & $\begin{array}{l}0.1 \\
0.5 \\
1.0 \\
1.2 \\
2.8\end{array}$ & $\begin{array}{r}0.2 \\
16.6 \\
50.6 \\
28.6 \\
96.0\end{array}$ & $\begin{array}{r}0.3 \\
3.5 \\
9.0 \\
6.8 \\
19.6\end{array}$ & $\begin{array}{l}0.0 \\
0.1 \\
2.4 \\
3.8 \\
6.3\end{array}$ & & & $\begin{array}{l}0.1 \\
0.5 \\
1.1 \\
1.6 \\
3.3\end{array}$ & $\begin{array}{r}2.4 \\
5.4 \\
13.6 \\
49.8 \\
71.2\end{array}$ & $\begin{array}{r}6.6 \\
13.2 \\
29.0 \\
39.0 \\
87.8\end{array}$ & $\begin{array}{r}1.0 \\
5.3 \\
11.0 \\
7.4 \\
24.7\end{array}$ & $\begin{array}{r}0.4 \\
1.0 \\
4.4 \\
5.2 \\
11.0\end{array}$ \\
\hline & Rabbit & \multicolumn{6}{|c|}{$\mathrm{C}$} & \multicolumn{5}{|c|}{ D } \\
\hline & & \multicolumn{6}{|c|}{ Days } & \multicolumn{5}{|c|}{ Days } \\
\hline & & 0 & 2 & 6 & 9 & 13 & 16 & 0 & 3 & 6 & 9 & 13 \\
\hline $\begin{array}{l}\text { Increasing ma- } \\
\text { turity of re- } \\
\text { ticulocytes } \\
\text { from I to IV }\end{array}$ & $\begin{array}{c}\text { I } \\
\text { II } \\
\text { III } \\
\text { IV } \\
\text { Total }\end{array}$ & $\begin{array}{l}0.2 \\
0.9 \\
2.0 \\
3.5 \\
6.6\end{array}$ & $\begin{array}{r}1.2 \\
6.4 \\
56.0 \\
33.2 \\
96.8\end{array}$ & $\begin{array}{r}0.6 \\
3.0 \\
14.8 \\
22.8 \\
41.2\end{array}$ & $\begin{array}{r}0.6 \\
1.1 \\
7.2 \\
9.4 \\
18.3\end{array}$ & $\begin{array}{r}0.1 \\
0.6 \\
3.9 \\
5.5 \\
10.1\end{array}$ & $\begin{array}{l}0.1 \\
0.5 \\
2.5 \\
6.5 \\
9.6\end{array}$ & $\begin{array}{l}0.0 \\
0.1 \\
0.6 \\
1.2 \\
1.9\end{array}$ & $\begin{array}{r}0.6 \\
2.6 \\
7.8 \\
38.0 \\
49.0\end{array}$ & $\begin{array}{r}0.2 \\
6.4 \\
17.2 \\
30.0 \\
53.8\end{array}$ & $\begin{array}{r}0.2 \\
1.5 \\
10.2 \\
11.7 \\
23.6\end{array}$ & $\begin{array}{r}0.0 \\
0.2 \\
4.9 \\
7.5 \\
12.6\end{array}$ \\
\hline
\end{tabular}

TABLE II

Total and differential (Heilmeyer) reticulocyte counts, and erythrocyte protoporphyrin content, in a dog with acute phenylhydrazine anemia

Six hundred mgm. of phenylhydrazine hydrochloride were given in divided doses during the first 5 days. The values given for the reticulocytes are percentages in all instances.

\begin{tabular}{|c|c|c|c|c|c|c|}
\hline & \multirow{2}{*}{ Group } & \multicolumn{5}{|c|}{ Days } \\
\hline & & 0 & 4 & 6 & 9 & 19 \\
\hline \multirow[t]{2}{*}{$\begin{array}{l}\text { Increasing ma- } \\
\text { turity of re- } \\
\text { ticulocytes } \\
\text { from I to IV }\end{array}$} & $\begin{array}{l}\text { II } \\
\text { III } \\
\text { IV }\end{array}$ & $\begin{array}{l}0.1 \\
0.2 \\
0.3 \\
0.5\end{array}$ & $\begin{array}{l}0.6 \\
2.5 \\
4.7 \\
9.1\end{array}$ & $\begin{array}{r}4.0 \\
10.0 \\
16.0 \\
12.0\end{array}$ & $\begin{array}{l}0.8 \\
1.8 \\
5.2 \\
8.1\end{array}$ & $\begin{array}{l}0.2 \\
0.9 \\
2.1 \\
3.0\end{array}$ \\
\hline & Total & 1.1 & 16.9 & 42.0 & 15.9 & 6.2 \\
\hline $\begin{array}{l}\text { Protoporphyrin } \\
\text { in } \gamma \text { per } 100 \\
\text { ml. of whole } \\
\text { blood }\end{array}$ & & 14.0 & 23.0 & 51.0 & 30.0 & 20.0 \\
\hline
\end{tabular}

in the group. The difference could not be related to a higher percentage of younger reticulocytes (Table I). In general, the time correlation between reticulocyte and protoporphyrin increase and decrease, is seen to be very close. The same parallelism was noted in 1 experiment in a dog (Table II).

The combined protoporphyrin solutions, from all of the above experiments, were subjected to the chromatographic method of purification, as described in Paper I of this series. Precipitated calcium carbonate powder (Cenco) was used as adsorbent, and benzene-petroleum ether $(1: 1)$ as solvent. The chromatogram was developed with benzene alone. Crystalline protoporphyrin 9 dimethyl ester (M.P. $219^{\circ}$ C.) was isolated (Figure 2). The spectroscopic properties were identical with those of pure protoporphyrin, as obtained from hemoglobin by the method previ-

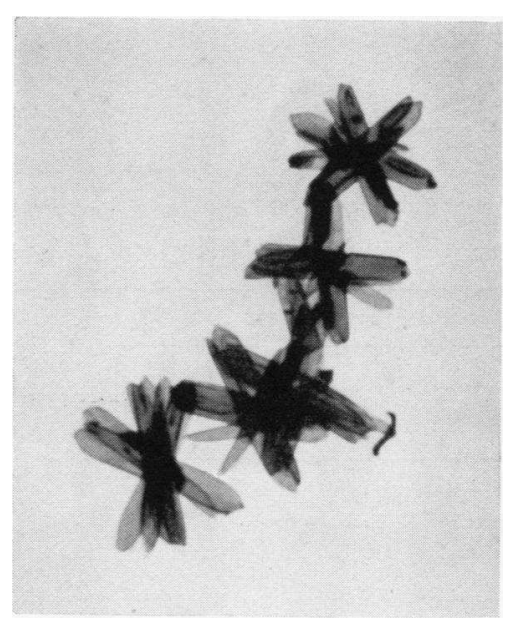

Fig. 2. Crystals of Protoporphyrin 9 Dimethyl Ester (IsOMer Type III) As IsOlated From ERYthroCytes of Rabbits with Acute Phenylhydrazine ANEMia 
ously described (11). This confirms the report of Grotepass (3) that the erythrocyte-protoporphyrin is the type 9 isomer. It may be noted that Grotepass' isolation was from normal human erythrocytes.

2. The second part of the study consisted in observing the amount of protoporphyrin in the erythrocytes, and the reticulocyte percentage, in 8 cases of pernicious anemia, before and at various periods after intramuscular injection of con- centrated liver extract. The data obtained from the first 7 of these are shown in Figure 3, while those from the eighth case, which was studied recently, are given in Figure 4 . It is seen that there is a lack of any close correlation, and, in several instances, even a marked divergence of the reticulocyte and protoporphyrin curves. The differences noted are obviously not related to variations in percentage of younger reticulocytes (Table III). In general, the peak in the proto-

TABLE III

Values for differential reticulocyte percentages, hemoglobin, red blood cells, and color index in pernicious anemia cases, before and after parenteral liver extract therapy

Color indices were calculated on the basis of 17 grams of hemoglobin per $100 \mathrm{cc}$. and 5,000,000 red blood cells per c. $\mathrm{mm}$. Hemoglobin determinations were made with the Evelyn photoelectric colorimeter.

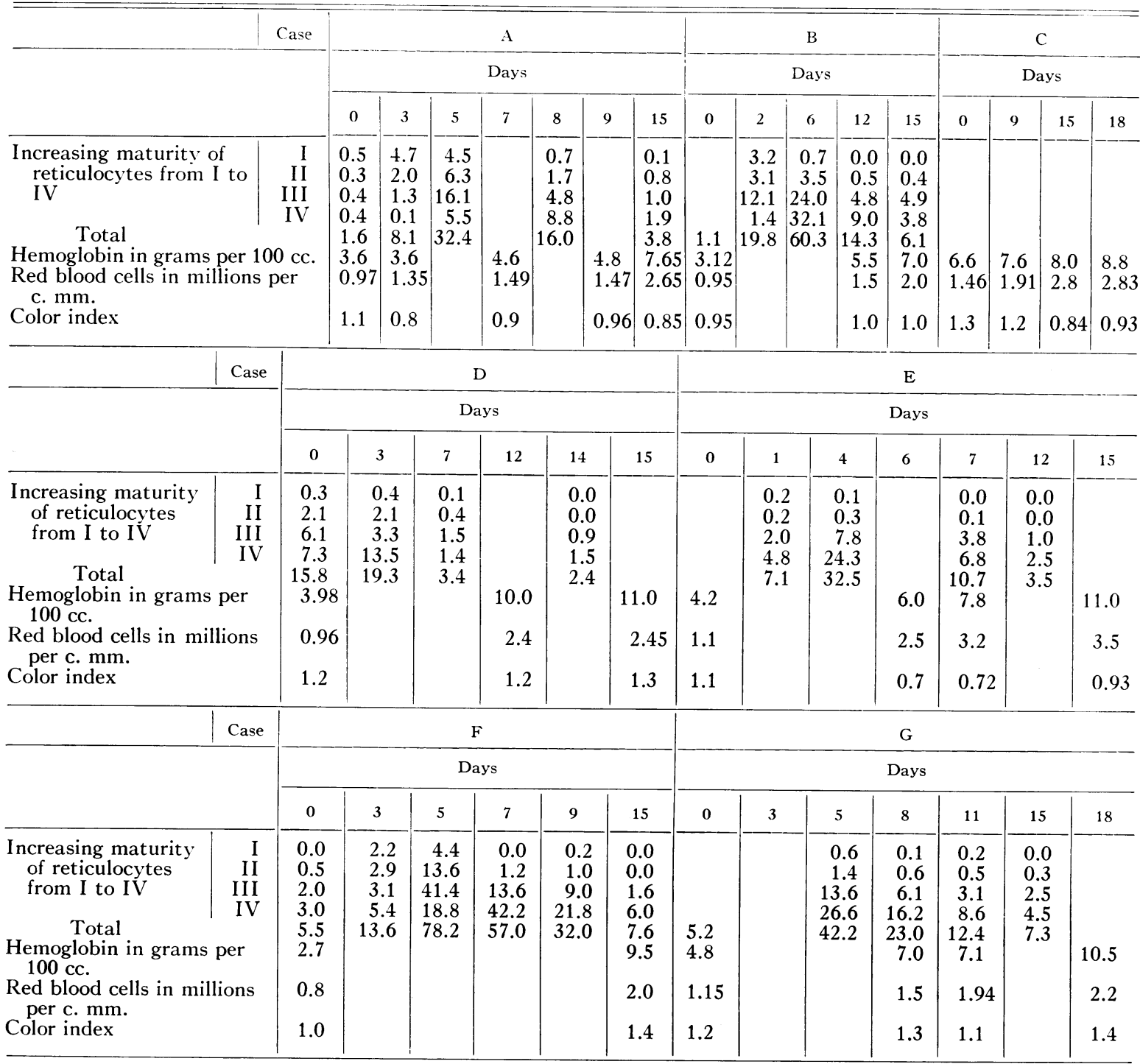




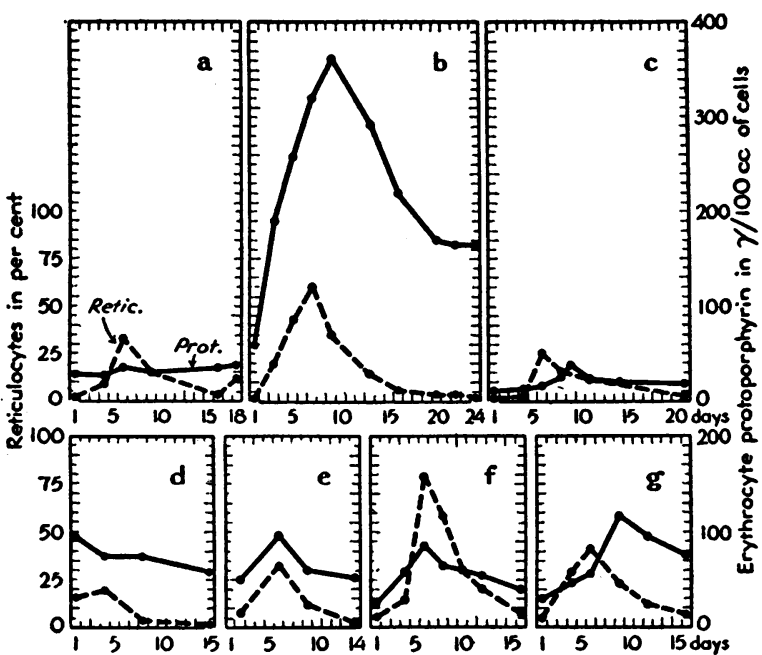

Fig. 3. Erythrocyte Protoporphyrin Concentration and Reticulocyte Percentage in 7 Cases (a to g) of Pernicious Anemia, as Affected by Liver EXTRACT THERAPY

In each instance an amount of 30 to 40 U.S.P. units of anti-anemic substance was injected intramuscularly on the first day.

porphyrin curve is attained later than that of the reticulocytes. This is particularly well shown in
Figure 4. The possibility must be considered that this delayed rise of the protoporphyrin is due to a developing iron deficiency. Our data on this point are somewhat fragmentary, but judging from the color indices given in Table III, and the hemoglobin concentrations shown in Figure 4, there is no evidence of any appreciable iron deficiency. Only in case e (Figure 3) was there any considerable decrease of the color index, and it may be noted that it later returned to the normal range without iron therapy, so that the significance with respect to iron deficiency is questionable.

It is noteworthy that the protoporphyrin values in the pernicious anemia cases prior to treatment were either low or normal, as compared with the data for supposedly normal individuals (Table IV). Furthermore, the increases following liver extract therapy were for the most part relatively small. The pernicious anemia data in Figure 3 and 4 may also be compared with those obtained in various diseases as shown in Table $\mathrm{V}$. We do not consider that the values given in Table IV necessarily represent the normal in all instances.

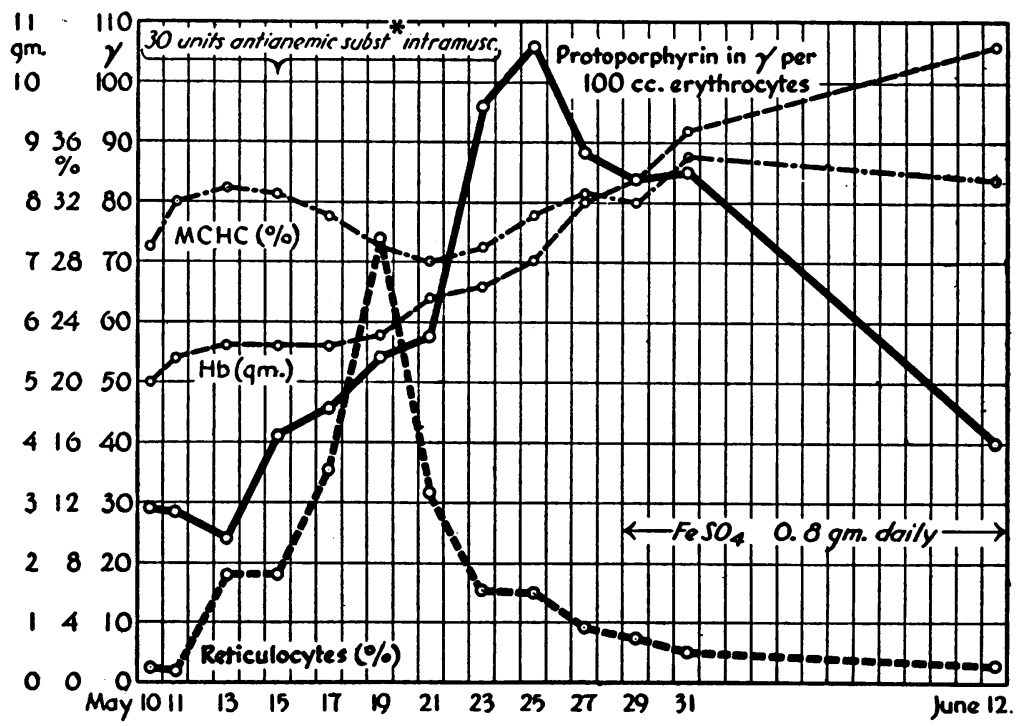

Fig. 4. Erythrocyte Protoporphyrin Concentration, Reticulocyte Percentage, Hemoglobin in grams per 100 cc. of Blood, and Hemoglobin Concentration of the Erythrocytes, Before and After Liver Extract Therapy in a Case of Pernicious Anemia

C. S., M, 53.

* Liver concentrate, 10 units per cc., intramuscularly, on May 10th; this dose was repeated on May 27. 
TABLE IV

Erythrocyte protoporphyrin in supposedly normal individuals (interns and nurses ranging in age from 20 to 25 years)

\begin{tabular}{c|c|c|c}
\hline \hline Number & Sex & $\begin{array}{c}\text { Hematocrit } \\
\text { percentage }\end{array}$ & $\begin{array}{c}\text { Erythrocyte } \\
\text { protoporphyrin }\end{array}$ \\
\hline 1 & F & 37.2 & 40.3 \\
2 & F & 37.6 & 45.7 \\
3 & F & 36.8 & 31.3 \\
4 & F & 40.1 & 34.9 \\
5 & M & 48.0 & 22.0 \\
6 & M & 43.0 & 26.7 \\
7 & M & 45.7 & 22.0 \\
8 & M & 48.0 & 19.7 \\
9 & M & 46.0 & 27.2 \\
10 & M & 44.0 & 23.8 \\
11 & M & 47.3 & 35.9 \\
12 & M & 45.2 & 30.9 \\
\hline
\end{tabular}

The 4 females included in this group were all student nurses, and it is noteworthy that a mild reduction of hematocrit percentage was present in 3 of these. It may be that the lowered hematocrit values are correlated with the increased amounts of erythrocyte protoporphyrin, these latter being somewhat greater than those observed in the males (healthy interns). Since mild anemia in otherwise normal young adult females is commonly related to increased menstrual blood loss, a further study of the erythrocyte protoporphyrin, with respect to the menstruation factor, is desirable. The data for the cases of post-hemorrhagic anemia, as seen in Table $\mathrm{V}$, clearly reveal considerable increases.

3. The third part of the study was concerned with incubation experiments. Blood samples were drawn under sterile precautions from the animals and patients, as noted in Table VI, $a$ and b. Potassium oxalate was used as anti-coagulant. The protoporphyrin content was determined at once on one-half of each sample, while the other half was incubated at $37^{\circ} \mathrm{C}$. for 24 to 48 hours, after which, the amount of protoporphyrin was determined again. Since the volume of the erythrocytes increases upon incubation, it was necessary to determine the hematocrit percentage both before and afterwards and to make correction for the percentage increase in volume. In each instance, it was determined by culture that no growth of bacteria had occurred. This comparison before and after incubation was made primarily with the thought that if the protoporphyrin were fundamentally related to the substantia reticulo-filamentosa, a sharp diminution in amount

TABLE V

Erythrocyte protoporphyrin and reticulocyte percentage in various pathological states

\begin{tabular}{|c|c|c|c|c|c|}
\hline Case & Sex & Age & Diagnosis and remarks & $\begin{array}{l}\text { Protoporphyrin } \\
\text { in } \gamma \text { per } 100 \propto c . \\
\text { of erythrocytes }\end{array}$ & $\begin{array}{c}\text { Reticulocyte } \\
\text { percentage }\end{array}$ \\
\hline 1. A. B. & $\mathbf{F}$ & 48 & Hypochromic anemia; menorrhagia & $\begin{array}{l}153.0 \\
178.0\end{array}$ & $\begin{array}{l}2.0 \\
4.1\end{array}$ \\
\hline 2. S. D. & $\mathbf{M}$ & 58 & $\begin{array}{l}\text { Hypochromic anemia; bronchial bleeding (after multiple } \\
\text { transfusions) }\end{array}$ & $\begin{array}{r}277.0 \\
95.0\end{array}$ & $\begin{array}{l}5.4 \\
3.3\end{array}$ \\
\hline 3. A. H. & $\mathbf{M}$ & 60 & Hypochromic anemia; bleeding duodenal ulcer & 221.1 & 0.9 \\
\hline 4. H. B. & $\mathbf{M}$ & 63 & Hypochromic anemia; bleeding duodenal ulcer & 103.4 & 1.2 \\
\hline 5. M. J. & $\mathbf{F}$ & 50 & Hypochromic anemia; bleeding duodenal ulcer & 50.0 & 0.7 \\
\hline 6. I. S. & $\mathbf{F}$ & 65 & $\begin{array}{l}\text { Advanced hepatic cirrhosis with moderate jaundice and } \\
\text { anemia. Ascites. No bleeding. Color index } 1.0\end{array}$ & 115.0 & 4.2 \\
\hline 7. C. $Q$. & $\mathbf{F}$ & 54 & $\begin{array}{l}\text { Cirrhosis with chronic jaundice and mild anemia. M. C. C. } \\
35 \text { per cent. Color index } 1.0\end{array}$ & 34.5 & \\
\hline 8. H. C. & $\mathbf{F}$ & 41 & $\begin{array}{l}\text { Primary common duct cancer with complete biliary ob- } \\
\text { struction. No bleeding. Color index } 1.0\end{array}$ & 69.0 & 5.8 \\
\hline 9. L. L. & $\mathbf{M}$ & 67 & $\begin{array}{l}\text { Leukemia with myelopthisic anemia, after many blood } \\
\text { transfusions. Color index } 1.0\end{array}$ & 43.0 & 0.0 \\
\hline 10. G. S. & $\mathbf{F}$ & 55 & Pernicious anemia, untreated & 10.0 & 2.2 \\
\hline 11. S. T. & $\mathbf{F}$ & 60 & Pernicious anemia, untreated & 24.0 & 3.4 \\
\hline
\end{tabular}


ERYTHROCYTE PROTOPORPHYRIN AND RETICULOCYTES

TABLE V

Erythrocyte protoporphyrin in various pathological states, continued.

\begin{tabular}{|c|c|c|c|c|c|c|c|c|c|}
\hline Case & Sex & Age & Diagnosis and remarks & Date & $\begin{array}{l}\text { Protopor- } \\
\text { phyrin in } \\
\text { per } 100 \text { cc. of } \\
\text { erythrocytes }\end{array}$ & $\begin{array}{l}\text { Reticu- } \\
\text { locyte } \\
\text { per- } \\
\text { centage }\end{array}$ & $\begin{array}{l}\text { Hemo- } \\
\text { globin in } \\
\text { grams per } \\
100 \text { cc. }\end{array}$ & $\begin{array}{l}\text { Hema- } \\
\text { tocrit } \\
\text { per- } \\
\text { centage }\end{array}$ & $\begin{array}{l}\text { M.C.H.C. } \\
\text { per- } \\
\text { centage }\end{array}$ \\
\hline \multirow[t]{5}{*}{ 12. A. H. } & \multirow[t]{5}{*}{$\mathbf{F}$} & \multirow[t]{5}{*}{63} & \multirow[t]{5}{*}{$\begin{array}{l}\text { Macrocytic (acquired) } \\
\text { hemolytic anemia }\end{array}$} & $\begin{array}{l}\text { May } 1,1943 \\
\text { May } 5,1943\end{array}$ & $\begin{array}{l}87 \\
78.2\end{array}$ & $\begin{array}{l}31 \\
30\end{array}$ & $\begin{array}{l}6.75 \\
6.00\end{array}$ & $\begin{array}{l}23 \\
23\end{array}$ & $\begin{array}{l}29 \\
26\end{array}$ \\
\hline & & & & \multicolumn{2}{|c|}{ Blood transfusions } & & & & \\
\hline & & & & $\begin{array}{l}\text { May } 11,1943 \\
\text { May } 13,1943 \\
\text { May } 15,1943 \\
\text { May } 17,1943\end{array}$ & $\begin{array}{r}105.8 \\
99.9 \\
54.1 \\
56.3\end{array}$ & $\begin{array}{r}14.8 \\
14.8 \\
9.1 \\
7.8\end{array}$ & $\begin{array}{c}8.75 \\
9.25 \\
9.7 \\
11.7\end{array}$ & $\begin{array}{l}28 \\
29 \\
29.8 \\
32.0\end{array}$ & $\begin{array}{l}31 \\
32 \\
32 \\
36\end{array}$ \\
\hline & & & & \multicolumn{2}{|c|}{ Splenectomy May 17, 1943} & & & & \\
\hline & & & & & & 9.9 & 1.40 & 24.0 & 31 \\
\hline 13. F. L. & $\mathbf{F}$ & 44 & $\begin{array}{l}\text { Post-hemorrhagic, hypo- } \\
\text { chromic anemia due to } \\
\text { bleeding hemorrhoids. } \\
\text { Iron therapy commenced } \\
\text { on May } 18,0.8 \text { grams } \\
\text { FeSO daily from that } \\
\text { date on }\end{array}$ & $\begin{array}{l}\text { May } 21,1943 \\
\text { May } 23,1943 \\
\text { May } 25,1943 \\
\text { May } 27,1943 \\
\text { May } 29,1943 \\
\text { June } 1,1943 \\
\text { June } 3,1943 \\
\text { June } 7,1943 \\
\text { June } 10,1943 \\
\text { June } 12,1943 \\
\text { June } 15,1943 \\
\text { June } 21,1943\end{array}$ & $\begin{array}{l}613.0 \\
623.0 \\
600.0^{*} \\
545.4 \\
427.0 \\
407.0 \\
266.6 \\
348.0 \\
121.0 \\
80.0 \\
73.0 \\
40.0\end{array}$ & $\begin{array}{l}6.2 \\
6.0 \\
6.8 \\
6.0 \\
7.1 \\
7.5 \\
5.3 \\
3.2 \\
4.0 \\
3.2 \\
2.1 \\
1.4\end{array}$ & $\begin{array}{l}5.75 \\
6.68 \\
6.68 \\
6.5 \\
8.0 \\
8.05 \\
9.3 \\
9.11 \\
11.1 \\
10.5 \\
11.4 \\
11.2\end{array}$ & $\begin{array}{l}23.0 \\
24.0 \\
24.1 \\
25.0 \\
26.2 \\
29.0 \\
30.0 \\
31.0 \\
31.0 \\
37.5 \\
35.0 \\
36.2\end{array}$ & $\begin{array}{l}25 \\
27.8 \\
27.8 \\
26.0 \\
30.0 \\
28.0 \\
30.0 \\
29.0 \\
35.0 \\
32.0 \\
32.0 \\
31.0\end{array}$ \\
\hline 14. P. B. & $\mathbf{M}$ & 63 & $\begin{array}{l}\text { Familial hemolytic jaun- } \\
\text { dice }\end{array}$ & May 25, 1943 & 37.0 & 5.9 & 11.7 & 32 & 33 \\
\hline 15. I. H. & $\mathbf{F}$ & 38 & $\begin{array}{l}\text { Familial hemolytic jaun- } \\
\text { dice }\end{array}$ & June 15, 1943 & 42.0 & 5.3 & 2.7 & 8 & 34 \\
\hline
\end{tabular}

* The porphyrin on this date was shown to be wholly chloroform soluble (protoporphyrin).

TABLE V

Erythrocyte protoporphyrin in various pathological states, continued

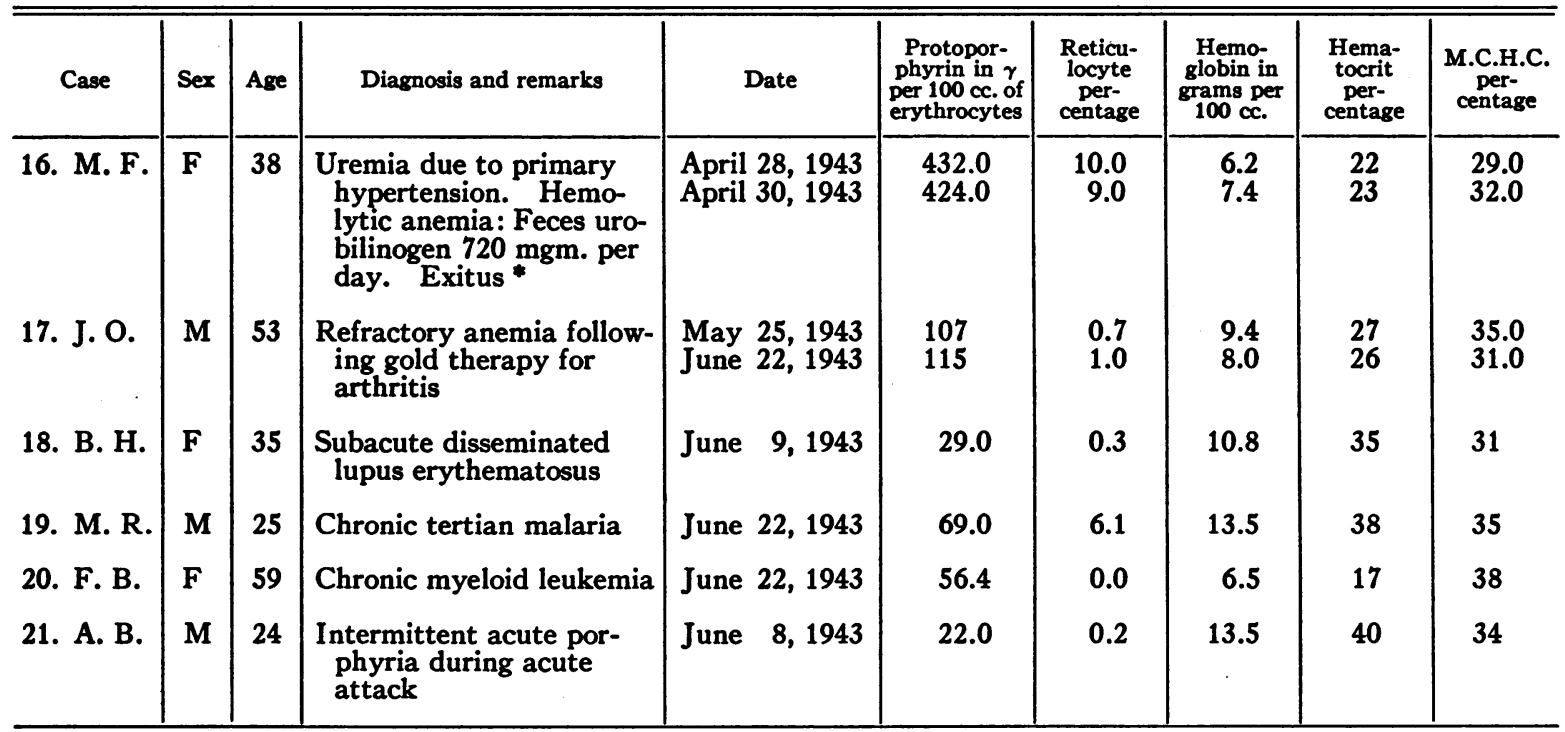

* In this case, the bone marrow of the shaft of the femur was red and hyperplastic. Approximately 2 grams of this red marrow were first ground and mashed with physiological saline in a mortar, then extracted for protoporphyrin as in the method for erythrocytes (13). No fluorescence was demonstrable in the final $\mathrm{HCl}$. The same was true of a similar amount of fresh spleen, similarly treated. From this, it would appear that the fixed cells of the bone marrow and spleen do not contain porphyrin. This would apply particularly to reticulo-endothelial cells and probably to early erythroblasts, but not to normoblasts. 
might be expected during incubation, since it is well-established that the majority of the reticulocytes mature, or at least lose their ability to stain supravitally, after 24 to 72 hours (15). Surprisingly, however, it was found that the protoporphyrin of the erythrocytes regularly increased upon incubation. The data are given in Tables VI, $a$ and $b$.

4. Further observations were made of the behaviour of dilute mixtures of brilliant cresyl blue and protoporphyrin. Watson and Clarke (4) noted that a precipitate was readily obtained from dilute solutions of the two substances, and that the microscopic appearance of this precipitate bore strik-

TABLE VIa

Increase of erythrocyte protoporphyrin during incubation of whole blood under sterile conditions

\begin{tabular}{|c|c|c|c|}
\hline Subject & $\begin{array}{c}\text { Time } \\
\text { in } \\
\text { hours }\end{array}$ & $\begin{array}{l}\text { Reticu- } \\
\text { locyte } \\
\text { per- } \\
\text { centage }\end{array}$ & $\begin{array}{l}\text { Protopor- } \\
\text { phyrin in } \gamma \\
\text { per } 100 \text { cc. of } \\
\text { erythrocytes; } \\
\text { whole blood }\end{array}$ \\
\hline $\begin{array}{l}\text { Dog } \\
\text { Acute phenylhydrazine anemia }\end{array}$ & $\begin{array}{r}0 \\
24 \\
48\end{array}$ & $\begin{array}{r}16.9 \\
7.0 \\
2.8\end{array}$ & $\begin{array}{l}23^{*} \\
38^{*} \\
46^{*}\end{array}$ \\
\hline $\begin{array}{l}\text { Rabbit } \\
\text { Acute phenylhydrazine anemia }\end{array}$ & $\begin{array}{r}0 \\
24\end{array}$ & & $\begin{array}{l}108 \\
232\end{array}$ \\
\hline $\begin{array}{l}\text { Rabbit } \\
\text { Lead poisoning }\end{array}$ & $\begin{array}{r}0 \\
24\end{array}$ & & $\begin{array}{l}116.5^{*} \\
276.0^{*}\end{array}$ \\
\hline $\begin{array}{l}\text { M. S. F } 68 \\
\text { Polycythemia vera }\end{array}$ & $\begin{array}{r}0 \\
24 \\
48\end{array}$ & & $\begin{array}{l}18.0 \\
25.0 \\
30.0\end{array}$ \\
\hline $\begin{array}{l}\text { A. B. M } 63 \\
\text { Polycythemia vera }\end{array}$ & $\begin{array}{r}0 \\
24\end{array}$ & & $\begin{array}{l}55.0 \\
71.5\end{array}$ \\
\hline $\begin{array}{l}\text { A. B. F } 48 \\
\text { Menorrhagia; hypochromic } \\
\text { anemia }\end{array}$ & $\begin{array}{r}0 \\
24\end{array}$ & & $\begin{array}{l}51.5^{*} \\
61.0^{*}\end{array}$ \\
\hline $\begin{array}{l}\text { O. H. F } 39 \\
\text { Macrocytic hemolytic anemia }\end{array}$ & $\begin{array}{r}0 \\
24\end{array}$ & & $\begin{array}{l}58.0 \\
64.0\end{array}$ \\
\hline $\begin{array}{l}\text { N. C. F } 28 \\
\text { Chronic ulcerative colitis; } \\
\text { hypochromic anemia }\end{array}$ & $\begin{array}{r}0 \\
24 \\
48\end{array}$ & $\begin{array}{l}7.6 \\
5.3 \\
1.8\end{array}$ & $\begin{array}{r}64.0 \\
96.0 \\
106.0\end{array}$ \\
\hline $\begin{array}{l}\text { E. K. F } 62 \\
\text { Bleeding peptic ulcer; hypo- } \\
\text { chromic anemia }\end{array}$ & $\begin{array}{r}0 \\
24 \\
48\end{array}$ & & $\begin{array}{l}118.0 \\
129.0 \\
140.0\end{array}$ \\
\hline
\end{tabular}

ing resemblance to the "substantia reticulo-filamentosa" in blood films, stained supravitally with brilliant cresyl blue. Present observations indicate that the mutual precipitation of the two substances may not be due to formation of an actual compound, as at first thought, but rather to an effect of the porphyrin upon the relative solubility of the dye in buffered solutions having a $\mathrm{pH}$ approximating that of the blood. Thus, the addition of $1 \mathrm{cc}$. of 0.2 per cent brilliant cresyl blue in physiological saline, to $5 \mathrm{cc}$. of a phosphate buffer solution of $\mathrm{pH} 7.3$, results in the slow appearance of an almost imperceptible precipitate of the dye. In a solution, similarly prepared, but to which an amount of protoporphyrin barely sufficient to color is first dissolved in the $\mathrm{Na}_{2} \mathrm{HPO}_{4}$ which is to be employed in preparing $5 \mathrm{cc}$. $(\mathrm{pH}$ 7.3), the precipitate forms more rapidly and is more voluminous.

\section{DISCUSSION}

The results obtained in acute phenylhydrazine anemia in rabbits (Figure 1) are quite in accord with the concept that the erythrocyte protoporphyrin resides in the reticulocytes. This is not supported, however, by the data obtained in the cases of pernicious anemia, nor in the incubation experiments (Figures 3 and 4, and Table VI, respectively). In both of these groups, it is apparent that the erythrocyte protoporphyrin may increase as the reticulocyte percentage diminishes. It is also evident from the data in Table $\mathrm{V}$ that there is a lack of correlation between reticulocyte percentage and erythrocyte protoporphyrin concentration in various conditions. These results make it clear that the problem of the erythrocyte protoporphyrin is much more complex than was indicated in the earlier study of Watson and Clarke (4). The conclusion reached at that time, i.e., that the erythrocyte protoporphyrin "resided chiefly, if not solely, in the reticulocytes," was based upon a correlation of two observations: (1) The presence of the protoporphyrin in the reticulocyte-rich, upper strata of centrifuged blood, and (2) the presence of large amounts of protoporphyrin in samples of blood containing only reticulocytes. This conclusion appeared to be well grounded, and there is, in fact, no reason to doubt that under many circumstances, at least. the re- 
TABLE VIb

Increase of erythrocyte protoporphyrin during incubation of whole blood under sterile conditions

\begin{tabular}{|c|c|c|c|c|c|c|c|}
\hline \multirow{2}{*}{ Subject } & \multirow{2}{*}{ Time } & \multirow{2}{*}{ Reticulocytes } & \multirow{2}{*}{$\begin{array}{c}\text { Blood } \\
\text { incubated }\end{array}$} & \multirow{2}{*}{ Hematocrit } & \multirow{2}{*}{$\begin{array}{l}\text { Erythrocytes } \\
\text { calc. from } \\
\text { hematocrit }\end{array}$} & \multicolumn{2}{|c|}{ Protoporphyrin } \\
\hline & & & & & & Erythrocytes & Whole blood \\
\hline & hours & per cent & $c c$. & per cent & cc. & \multicolumn{2}{|c|}{$\gamma$ per cent } \\
\hline Polycythemia & $\begin{array}{r}0 \\
24 \\
48\end{array}$ & $\begin{array}{l}0.4 \\
0 \\
0\end{array}$ & $\begin{array}{l}13.0 \\
13.0 \\
12.0\end{array}$ & $\begin{array}{l}63.8 \\
74.8 \\
89.0\end{array}$ & $\begin{array}{r}8.29 \\
9.72 \\
10.68\end{array}$ & $\begin{array}{l}21.7 \\
38.0 \\
33.7\end{array}$ & $\begin{array}{l}13.8 \\
27.5 \\
30.3\end{array}$ \\
\hline $\begin{array}{l}\text { M. F. F } 38 \\
\text { Hypertension; chronic uremia. Hemo- } \\
\text { lytic anemia }\end{array}$ & $\begin{array}{r}0 \\
24 \\
48\end{array}$ & $\begin{array}{l}9.0 \\
6.0 \\
0.0\end{array}$ & $\begin{array}{r}15.0 \\
8.5 \\
7.5\end{array}$ & $\begin{array}{l}22.0 \\
26.2 \\
32.0\end{array}$ & $\begin{array}{l}3.3 \\
2.22 \\
2.4\end{array}$ & $\begin{array}{l}424.0 \\
406.4 \\
416.6\end{array}$ & $\begin{array}{r}93.2 \\
106.4 \\
132.1\end{array}$ \\
\hline $\begin{array}{l}\text { A. H. F } 63 \\
\text { Macrocytic hemolytic anemia }\end{array}$ & $\begin{array}{r}0 \\
24 \\
48\end{array}$ & $\begin{array}{l}30.0 \\
28.0 \\
26.0\end{array}$ & $\begin{array}{l}10.7 \\
10.8 \\
11.1\end{array}$ & $\begin{array}{l}24.0 \\
30.0 \\
33.0\end{array}$ & $\begin{array}{l}2.56 \\
3.24 \\
3.66\end{array}$ & $\begin{array}{l}78.2 \\
74.0 \\
76.5\end{array}$ & $\begin{array}{l}18.7 \\
22.0 \\
25.0\end{array}$ \\
\hline $\begin{array}{l}\text { F. H. F } 60 \\
\text { Pernicious anemia, untreated }\end{array}$ & $\begin{array}{r}0 \\
24 \\
48\end{array}$ & $\begin{array}{l}0.9 \\
0.7 \\
0.2\end{array}$ & $\begin{array}{l}10.2 \\
10.3 \\
11.8\end{array}$ & $\begin{array}{l}23.4 \\
33.2 \\
35.0\end{array}$ & $\begin{array}{l}2.38 \\
3.41 \\
4.13\end{array}$ & $\begin{array}{l}23.1 \\
23.4 \\
24.2\end{array}$ & $\begin{array}{l}5.4 \\
7.74 \\
9.9\end{array}$ \\
\hline $\begin{array}{l}\text { C. S. M } 53 \\
\text { Pernicious anemia, after treatment }\end{array}$ & $\begin{array}{r}0 \\
24 \\
48\end{array}$ & $\begin{array}{r}12.6 \\
8.0\end{array}$ & $\begin{array}{r}10.2 \\
10.0 \\
9.4\end{array}$ & & $\begin{array}{l}2.42 \\
2.8 \\
2.9\end{array}$ & $\begin{array}{l}\mathbf{5 7 . 8} \\
57.2 \\
65.5\end{array}$ & $\begin{array}{l}14.0 \\
16.0 \\
19.0\end{array}$ \\
\hline $\begin{array}{c}\text { W. E. M } 61 \\
\text { Periarteritis nodosa }\end{array}$ & $\begin{array}{r}0 \\
24 \\
48\end{array}$ & $\begin{array}{l}0.4 \\
0.4\end{array}$ & $\begin{array}{l}10.0 \\
10.0\end{array}$ & & $\begin{array}{l}2.9 \\
4.6\end{array}$ & $\begin{array}{l}155.2 \\
184.0\end{array}$ & $\begin{array}{l}45.0 \\
80.0\end{array}$ \\
\hline
\end{tabular}

ticulocytes are relatively rich in protoporphyrin. The available evidence now indicates, however, that there are at least two factors, in addition to erythropoietic activity, to explain the presence of protoporphyrin in the erythrocytes. The additional factors are believed to be: (1) Iron deficiency, and (2) formation of protoporphyrin from hemoglobin in intact erythrocytes.

The recent studies of Stasney and his co-workers (16) indicate that normoblasts contain protoporphyrin in considerable amount. This is in accord with the finding of protoporphyrin in the reticulocytes in experimental, acute phenylhydrazine anemia. It is also of interest to consider the present findings in pernicious anemia in relation to Stasney's observations on the porphyrin content of the bone marrow in this disease. Stasney was unable to find protoporphyrin in the megaloblastic marrow of pernicious anemia patients in relapse, but observed it in increasing amount as the marrow became more and more normoblastic, shortly after liver extract therapy. It should be pointed out that previous studies of the bone marrow porphyrin in pernicious anemia are not in accord. Thus, Borst and Königsdorffer (17) regularly noted protoporphyrin in the megaloblasts of pernicious anemia marrow, while Seggel and his coworkers were unable to find it, either before or after treatment. Nor could they observe it in any other condition (including hemolytic jaundice), with the one exception, however, of lead poisoning. The reports of both of these groups of investigators were based upon studies with the fluorescence microscope, while Stasney employed extraction of considerable amounts of marrow, and, after suitable fractionation, examined the final concentrated solution with ultraviolet light.

In the present study, the protoporphyrin values obtained for the circulating red cells in pernicious anemia, before liver therapy, were relatively low (Figures 3 and 4 ; Tables V and VIb). Increases are noted following treatment, but in most in- 
stances the highest level was reached only at some time after the reticulocyte peak. The reason for this is not clear. The possibility exists that most or at least many of the reticulocytes at the peak were derived from megaloblasts, and hence, if Stasney's observations be correct, contained little or no protoporphyrin; later, as more and more of the young circulating cells are derived from normoblasts, the protoporphyrin content would be expected to increase. Obviously, much more study of this problem is needed, together with simultaneous quantitative data on the bone marrow porphyrins.

Seggel also observed little or no protoporphyrin in the circulating red cells during relapse, a finding which was correlated with a negligible number of fluorescytes (10). Seggel regarded the increased fluorescyte percentage occurring after the reticulocyte peak as being due to iron deficiency. In the present study, however, evidence of iron deficiency during this period is not convincing. If one falls back upon the rapid regeneration (incomplete synthesis) theory of Seggel's, it would be logical to expect the two curves to be parallel. This was true in but 2 of the 6 cases shown (cases $e$ and $f$ in Figure 3 ). It is quite possible, however, that this is the explanation for the parallel curves noted in Figure 1 , where hemolysis and rapid regeneration were induced by phenylhydrazine.

Formation of protoporphyrin from hemoglobin in intact erythrocytes would appear to be the only explanation for the results of the present incubation experiments (Table VIa, b). That such a factor obtains in vivo has not been shown, but there is much reason to suppose that temporary sequestration of erythrocytes as, for example, in the splenic pulp, is comparable in many respects to sterile incubation in vitro (18 to 21 ).

The protoporphyrin value noted for the cases of leukemia with myelopthisic anemia (Cases 9 and 20 in Table V) in which no reticulocytes could be found, is likewise best explained on the basis of formation from hemoglobin. In neither of these cases was there any evidence of iron deficiency. The increased values observed in the hemolytic anemias may also be at least partly explained on this basis, while a part of the increase may be due, again, to incomplete synthesis on the basis of rapid regeneration. The consid- erable day to day fluctuation of amount, as noted in Case 12 (Table V), could be attributed to either mode of formation of the protoporphyrin. Assuming that protoporphyrin may be formed from hemoglobin in intact erythrocytes is not to say that it is an intermediate stage in the formation of bilirubin, against which some evidence, at least for the dog, has been described previously (22). Bilirubin has been shown to increase upon sterile incubation of erythrocytes (23), but the available evidence ( 23 to 26 ) indicates the presence of a biliverdin iron-globin, rather than protoporphyrin, as the intermediate compound.

The third factor deserving consideration is that of iron deficiency. It is logical to assume that unused protoporphyrin might be present in red blood cells which are hypochromic because of iron deficiency. Seggel and his co-workers have provided considerable evidence for this view (10), and the present data (Table V) are in agreement. The effect of iron therapy is particularly well shown in Case 13 (Table V).

The clinical data given in Table $\mathrm{V}$ make it evident that determination of the erythrocyte protoporphyrin is likely to be of considerable interest in the study of anemias generally, both as to classification and underlying pathologic physiology. It is not inconceivable that the method will have value in the detection of incipient damage due to heavy metals and other toxic agents. We have not yet determined the concentration in human cases of lead poisoning, but the data of others $(10,27)$, together with our own observations in rabbits, are indicative of the marked increases which occur. The considerable increase noted in the case of refractory anemia following gold therapy (Table V) suggests that the method may have value in this direction also.

Seggel (10) regards the increased protoporphyrin content of the erythrocytes in lead poisoning as due to interference in hemoglobin synthesis. Kench and his co-workers (27) are not in accord with this view, since their data indicated that the increased porphyrin formation (both proto and copro III) is much too small to correspond with the total reduction in amount of hemoglobin. This objection may or may not prove valid, since it is difficult to exclude other factors relating to a decreased amount of hemoglobin.

One of the most interesting of the present cases 
is that of the hemolytic, regenerative anemia associated with uremia (Case 16, Table V). The cause of the marked increase of erythrocyte protoporphyrin, but a few days before death, is not clear. One is tempted to assign it to a toxic hemolysis with associated disturbance of hemoglobin synthesis.

The present results do not appear to support the concept of an in vivo precipitation of brilliant cresyl blue and protoporphyrin as explaining the supravital staining phenomenon. This possibility was suggested by Watson and Clarke (4), but it was not proven, although others have subsequently stated, incorrectly, that Watson and Clarke's study proved identity of the basophilic substance of the reticulocytes with protoporphyrin (27). The data for the phenylhydrazine anemia rabbits, it is true, are quite compatible, and even suggestive, but the remaining studies, and especially the incubation experiments, are not in accord. The idea should probably not be entirely discarded, however, since it is conceivable that various factors might prevent an intracorpuscular protoporphyrin derived in one way from precipitating with the dye, while that formed in another way might readily do so. Protoporphyrin derived from hemoglobin, as in the incubation experiments, might not be effective, while that representing formative material not yet used in hemoglobin synthesis, as in the phenylhydrazine anemic rabbits, might easily serve to precipitate the dye during the supravital staining. In particular, the state of the erythrocyte protoporphyrin with respect to iron and protein under any given circumstances would merit further consideration in this respect.

\section{SUMMARY AND CONCLUSIONS}

1. In rabbits suffering from acute phenylhydrazine anemia, the curves of reticulocyte percentage and erythrocyte protoporphyrin content follow each other closely at various periods. The crystalline protoporphyrin, isolated from the erythrocytes in these experiments, was found to be isomer type 9 , corresponding to aetioporphyrin III.

2. In pernicious anemia patients, studied before and at various intervals after liver extract therapy, the erythrocyte protoporphyrin curves usually reached their peaks only at some time after the maximal reticulocyte percentages. This delayed rise is not correlated with the relative age of the reticulocytes, as determined by the amount of substantia reticulo-filamentosa. The possibility is considered that the first mass of reticulocytes appearing after liver therapy may be derived from megaloblasts and may not contain as much porphyrin as those derived from the normoblasts and entering the circulation a short time later.

3. Correlation was not observed between the reticulocyte percentage and erythrocyte protoporphyrin content in a series of observations in various diseases. Increased amounts of erythrocyte protoporphyrin were regularly observed in post-hemorrhagic, iron deficiency anemias. The amounts observed in hemolytic anemias, and in certain toxic states, were likewise considerably elevated. By comparison, the values observed in untreated cases of pernicious anemia were relatively low, and were within the normal range.

4. Sterile incubation of various blood samples, for from 24 to 48 hours, revealed a regular increase of the erythrocyte protoporphyrin. This increase occurred in spite of a decreasing reticulocyte percentage. The possibility is considered that erythrocyte protoporphyrin may be formed in vivo from hemoglobin, under certain circumstances.

5. At least three factors are thus held likely for the presence of the erythrocyte protoporphyrin: (1) Normoblastic activity in the bone marrow; (2) iron deficiency or interference in utilization of iron in hemoglobin synthesis; and (3) hemoglobin degradation in intact red blood cells.

\section{BIBLIOGRAPHY}

1. van den Bergh, A. A. H., and Hyman, A. J., Studien über Porphyrin. Deutsche med. Wchnschr., 1928, 54, 1492.

2. van den Bergh, A. A. H., Grotepass, W., and Revers, F. E., Beitrag über das Porphyrin in Blut und Galle. Klin. Wchnschr., 1932, 11, 1534.

3. Grotepass, W., Het porphyrine in normale bloedlichaampjes. Nederl. Tijdschr. v. geneesk., 1937, 81, 362.

4. Watson, C. J., and Clarke, W. O., The occurrence of protoporphyrin in the reticulocytes. Proc. Soc. Exper. Biol. and Med., 1937, 36, 65.

5. de Langen, C. D., and Grotepass, W., Zur Frage des Porphyrinstoffwechsel beim Auf- und Abbau des Blutes. Acta med. Scandinav., 1938, 94, 245. 
6. Keller, C. J., and Seggel, K. A., Uber das Vorkommen fluorescierender Erythrocyten. I. Untersuchungen am normalen roten Blutbild. Folia haemat., 1934, 52, 241.

7. Seggel, K. A., Uber das Vorkommen fluorescierender Erythrocyten. II. Untersuchungen an Anämiefällen des Menschen. Folia haemat., 1934, 52, 250.

8. Müller-Neff, H., Über das Vorkommen fluorescierender Erythrocyten. IV. Untersuchungen an Fluorescyten. Folia haemat., 1936, 56, 18.

9. Chytrek, E., Die Fluorescytenzahl im menschlichen und tierischen Blut und ihre mögliche Beeinflussung. Klin. Wchnschr., 1940, 19, 1321.

10. Seggel, K. A., Fluorescenzphänomen und Porphyringehalt der Erythrocyten. Ergebn. d. inn. Med. u. Kinderh., 1940, 58, 582.

11. Grinstein, M., and Watson, C. J., Studies of protoporphyrin I. The purification of protoporphyrin IX as obtained from hemoglobin. J. Biol. Chem., 1943, 147, 667.

12. Grinstein, M., and Watson, C. J., Studies of protoporphyrin II. A note on an improved micromethod for converting protoporphyrin to mesoporphyrin. J. Biol. Chem., 1943, 147, 671.

13. Grinstein, M., and Watson, C. J., Studies of protoporphyrin III. Photoelectric and fluorophotometric methods for the quantitative determination of the protoporphyrin in blood. J. Biol. Chem., 1943, 147, 675.

14. Heilmeyer, L., Blutfarbstoffwechselstudien. I. Probleme, Methoden, und Kritik der Whippleschen Theorie. Deutsches Arch. f. klin. Med., 1931, 171, 123.

15. Heath, C. W., and Daland, G. A., The life of the reticulocytes. Experiments on their maturation. Arch. Int. Med., 1930, 46, 533.

16. Stasney, J., and McCord, W. M., Serial bone marrow studies in pernicious anemia. III. Occurrence of protoporphyrin in human bone marrow. Proc. Soc. Exper. Biol. and Med., 1943, 51, 340.
17. Borst, M., and Königsdorffer, $H$., Untersuchungen über Porphyrie. S. Hirzel, Leipzig, 1929, p. 223.

18. Fahraeus, R., Erythrocytes-plasma interface and consequences of its diminution. Lancet, 1939, 2, 630.

19. Watson, C. J., and Paine, J. R., A study of the splenic venous blood. With particular reference to the hematocrit percentage and the hemoglobin concentration of the erythrocytes, before and after splenic arterial injection of adrenalin. Am. J. M. Sc., 1943, 205, 493.

20. Ham, T. H., and Castle, W. B., Studies on destruction of red blood cells. Relation of increased hypotonic fragility and of erythrostasis to the mechanism of hemolysis in certain anemias. Proc. Am. Philo. Soc., 1940, 82, 411.

21. Fagerberg, E., Fagerberg, S. E., and Fahraeus, R., La splénomégalie hyperémique, l'hémolyse intensifiée, l'augmentation du fibrinogène et la sédimentation accélérée des globules rouges. Acta med. Scandinav., 1941, 108, 1.

22. Watson, C. J., Pass, I. J., and Schwartz, S., A study of the supposed conversion of protoporphyrin to coproporphyrin by the liver. I. The fate of parenterally administered protoporphyrin in dogs with bile renal fistulae. J. Biol. Chem., 1941, 139, 583.

23. Barkan, G., Blutfarbstoff, Eisen, Gallenfarbstoff ; neuere Untersuchungen über eisenhaltige Begleiter des Hämoglobins. Klin. Wchnschr., 1937, 16, 1265.

24. Barkan, G., and Walker, B. S., The red blood cell as a source of the iron and bilirubin of the blood plasma. J. Biol. Chem., 1939, 131, 447.

25. Lemberg, R., Legge, J. W., and Lockwood, W. $\dot{H}$., A hemoglobin from bile pigment. Nature, 1938, 142, 148.

26. Engel, M., Quantitative Untersuchungen zur Gallenfarbstoffbildung in vitro. Ztschr. f. physiol. Chem., 1940, 266, 135.

27. Kench, J. E., Gillam, A. E., and Lane, R. E., Haemopoiesis in lead poisoning. Biochem. J., 1942, 36, 384. 